\title{
Nietzsche's Cow: On Memory and Forgetting
}

JS: The person who makes a shopping list is not the same person who reads it later. I find that intriguing and vaguely disturbing-but also liberating.

RB: Forgotten shopping lists, forgotten umbrellas, forgotten selves. Being-in-time. It is the paradigm for modernism. We discard the past so that we may create the future. Joyce memorably states the case in Ulysses: "As we weave and unweave our bodies from day to day, their molecules shuttled to and fro, so does the artist weave and unweave his image." And yet, our archetypal modernist - the man who read everything and forgot nothingadds the following: "through the ghost of the unquiet father the image of the unliving son looks forth ... So in the future, the sister of the past, I may see myself as I sit here now but by reflection from that which then I shall be."

JS: Does any great artist ever discard anything? It seems to me that, because nothing is lost on an artist, nothing ever is forgotten. The meanest memory that flowers often gives thoughts too deep for tears, to amend Wordsworth, that Übermemorymensch. Ulysses and The Waste Land are deeply memorial texts. The opposite of mad Ophelia is ominously sane Eliot, who can connect anything with anything precisely because his mind is a cultural echo-chamber-that is, memory's sonorous mausoleum. Why even speak of forgetting if this is the achievement of memory? One is tempted to construct a slippery sliding scale of memory/ forgetting, with shopping lists at one end and Ulysses at the other.

How to cite this book chapter:

Begam, R. and Soderholm, J. 20I5. Nietzsche's Cow: On Memory and Forgetting. In: Begam, R. and Soderholm, J. Platonic Occasions: Dialogues on Literature, Art and Culture. Pp. I42-1 58. Stockholm: Stockholm University Press. DOI: http://dx.doi.org/IO.I6993/sup.baa.i. License: CC-BY-NC-ND. 
RB: And yet Eliot, having suffered a mental breakdown, shores up his own ruined identity with a series of fragmented memories. You call him ominously sane, but he compares himself to mad Hieronymo, Kyd's counterpart to Ophelia. Remember what Eliot says in "Tradition and the Individual Talent": for the modern writer the entire history of literature "composes a simultaneous order." Isn't the inability to forget-to distinguish between the antecedent and the contemporary-a form of madness? To be modern is to absorb the past so completely that it becomes the present; but it is also to break with the present so completely that one risks breaking with one's self. Is modernism just another word for schizophrenia?

JS: Let me respond with a query. What did it mean when Stephen Dedalus said, "History is a nightmare from which I am trying to awake"? What does that nightmare consist of and what has our memory/forgetting dialectic to do with it?

RB: For Eliot the present is mad. For Joyce the past is a nightmare. Best to forget both?

JS: I take it that Nietzsche's cheerful "God is Dead" was an attempt to actively forget (aktive Vergesslichkeit) both his dismal present and all the values and beliefs associated with JudeoChristianity and Western metaphysics. Perhaps much of the vitality of modern art emerges from that murdering of present and past values and traditions, and yet one must know the traditions thoroughly in order to transmute, transvalue and transcend them. How one can actively forget-Nietzsche called that ability "a positive faculty of repression"-is a mystery. Emerson called it "selfreliance" in his essay by that name. But it would seem that only those who are deeply steeped in the past create anything worthwhile in the very attempt to forget it. That's why "April is the cruellest month" mixing memory and desire, at once nodding to Chaucer's famous opening in the "General Prologue" and pushing far beyond it. I wonder if the shallowness of so much contemporary art-not to mention the superficiality of so many human beings-results from having almost no literary, philosophical or historical memory. 
RB: There are two ways to be contemporary: consciously and unconsciously. The first we call modernism, the second solipsism. One is reminded of Nietzsche's happy cow from the Second of the Untimely Meditations. It forgets nothing because it remembers nothing. Each mouthful of grass is as delicious as the last. And it is struck with wonder and admiration at every one of its evacuations, as though it had just produced the Mona Lisa from its hindquarters.

JS: Those cows have been pasturing in my imagination for decades. What is remarkable is how closely human beings can be herd-like in their capacity for passive forgetting and the form of solipsism you mention. I suppose I have always looked to art for solace and succour because it represents the opposite of the oblivious cow. But it is difficult to avoid the nightmare of history unless one is an artist or a highly-artistic interpreter, with all the madness those roles may entail. Better to be a lunatic than a happy cow? And yet I thought our Zen-masters taught us to live in the present.

RB: Our Zen-masters teach us to welcome both the nightmare and the madness. Without them we cannot be truly modern. No doubt you recall the beginning of Joyce's Portrait: “Once upon a time and a very good time it was there was a moo-cow coming down along the road ..." It is an exercise in modernist forgetting and remembering, in making the new out of the old.

The most ancient of story-telling formulas is transformed into something modern when we realize that Joyce has placed it in ironic quotation marks. And what about our four-legged friend, the little moo-cow? I like to think she has wandered in from Nietzsche's Second Meditation, a reminder that to be modern is necessarily to be out of joint with one's time, at once unzeitgemäss and unzeitig.

JS: I am inescapably (not that I have any wish to escape) reminded of Hamlet's last lines in Act I, scene 5, when, having just seen his unquiet ghost-father and realized the horrible revenge he must pursue, he remarks: "The time is out of joint. / $\mathrm{O}$ cursèd spite that ever I was born to set it right."

Is Hamlet the first modernist? Two scenes later he will say, in his first soliloquy, "Heaven and earth-must I remember?" 
Hamlet the Malcontent, driven to lunacy-both premeditated and unpremeditated-an unliving son looking forth at the duty to kill Claudius and wishing he had never been born, already plumping for "not to be." No wonder that Shakespeare's play is remembered in Ulysses more than any other text, including The Odyssey.

RB: Both Hamlet and Stephen are history-haunted, the one by the ghost of the father, the other by the ghost of the mother. But these characters stand in strikingly different relations to their pasts. Hamlet is the defender of tradition. For him the time is out of joint not because it lacks a natural order, but because that natural order has been violated by Claudius and Gertrude. Although Hamlet is not temperamentally suited for the task before him ("O cursèd spite"), he knows what it is and dedicates himself to achieving it.

Stephen also bears the burden of an oppressive historical memory: the violation and subjugation of Mother Ireland. But unlike Hamlet, Stephen has no desire to restore his ancestral patrimony, turning away in disgust from both Irish nationalism and English imperialism. The model he takes for himself is not Hamlet but Shakespeare; hence, his "theory" of Hamlet in which Stephen "proves by algebra" that Shakespeare "is the ghost of his own father."

What could be more modern than to become one's own precursor? The most radical of Harold Bloom's revisionary ratios is apophrades: the dead return but as imitations of the living. Hamlet avenges the ghost of the past; Joyce becomes that ghost.

JS: Harold Bloom blooms an Apophrades Complex. Shall I number those streaks? Hamlet's problem (from Coleridge to the present) is that he has no desire to be Prince and restore anything patrimonial. He is far too matri-moanial to re-mind himself of his Conventional Revenge. By Act 5, scene 2, he has (as our students would say) "like totally forgotten his dead dad" and the imperatives that would Spanish-tragedy him (has "Spanish-tragedy" ever drawn its blade as a verb?) into "to be." Revenge is the mother of compression. All of these abstruse musings dally in the most efficient memory-and-forgetting line ever penned by that mortal 
god from Stratford: "Thrift, thrift, Horatio-the funeral baked meats / Did coldly furnish forth the marriage table."

RB: By Act 5, scene 2 Hamlet has "totally forgotten his dead dad" and the "imperatives" of revenge tragedy? Then please explain the following:

HORATIO:

So Guildenstern and Rosencrantz go to't.

HAMLET:

They are not near my conscience; their defeat

Does by their own insinuation grow.

'Tis dangerous when the baser nature comes

Between the pass and fell incensèd points

Of mighty opposites.

HORATIO:

Why, what a king is this!

HAMLET:

Does it not, think thee, stand me now upon-

He that hath killed my king and whored my mother,

Popped in between th' election and my hopes,

Thrown out his angle for my proper life,

And with such coz'nage-is it not perfect conscience? (V.ii.56-66)

Hamlet is bent on bloody revenge ("Between the pass and fell incensèd points / Of mighty opposites), a revenge inspired by the memory of a betrayed and murdered father ("He that hath killed my king and whored my mother”).

Hamlet is modern in his psychology, but not in his timeconsciousness. He doesn't want to overcome the past. He wants to restore its lost order.

JS: A palpable hit. But Johnson was right to see that the catastrophe in Act 5 is not felicitously brought about. It is nearly a deus ex machina. Hamlet does not avenge his father's death. He avenges his own, and perhaps his mother's. And he seems steeped in Christian resignation ("There's a divinity that shapes our ends") after he returns to Denmark. Hamlet is the ultimate puzzle when it comes to the memory-forgetting dynamic. That he was born to put time into 
its joint is a cursed fact for him. And he knows that no matter what he does, he will end up like Alexander and Caesar: clay stopping up a beer barrel. Yorick is both his past and his future, all of our futures.

RB: This is the same Samuel Johnson who preferred the revised version of King Lear in which Cordelia comes back to life at the end? I myself think the catastrophe is masterfully wrought and that Shakespeare makes perfectly clear that Hamlet hashowever belatedly—avenged his father:

\section{HAMLET:}

The point envenomed too?

Then venom, to thy work ...

Here, thou incestuous, murd'rous, damnèd Dane,

Drink off this potion. Is thy union here?

Follow my mother. [King dies]

\section{LAERTES:}

He is justly served. (V.ii.304-5; 308-10)

Hamlet, as we discussed in another dialogue, is caught between two worlds-one Pagan, one Christian. What he has learned at Wittenberg, where he would have studied theology and philosophy, has made him a good scholar but a bad prince-a man more concerned with "conscience" (V.ii.56-66) than vengeance. It is precisely that internal division between the Pagan and the Christian that unsuits him for action, indeed for Kingship. As you noted, in the graveyard scene it is Alexander and Caesar who are consigned to dusty mortality. What do they have in common? They were the two greatest soldiers of antiquity-men of action who would have slain Claudius in Act I, scene 2-and they were pagan. When Hamlet goes metaphysical, as he does with Yorick, he is yearning to go Christian. So too in the "quintessence of dust" speech.

If Hamlet were a little more pagan, he would have dispatched Claudius in Act 3, scene 3 ("Now might I do it pat"). If he were a little more Christian, he would have gotten the hell out of barbarous Helsingor. As a pagan, he lives in historical time, and it is his duty to set that time right. As a Christian, he hopes to tran- 
scend historical time, and it is his duty to save his immortal soul. But in neither case can we say of Hamlet what Adorno says of modernism: "Now modern art is different from all previous art in that its mode of negation is different. Previously, styles and artistic practices were negated by new styles and practices. Today, however, modernism negates tradition itself." Hamlet not only does not negate tradition itself. He acts to uphold it.

JS: I don't see how Adorno's view has any weight when it comes to either Ulysses or The Waste Land. Neither work negates tradition. They digest it thoroughly, as Eliot claimed in his famous essay. Modernism negating Tradition? I should have thought that these two seminal works of modernism were at once thoroughly Traditional and utterly Individual. Negating and blithely forgetful texts are superficial and boring.

RB: Ulysses and The Waste Land are not apostrophes to the past but apophrades, which is to say, Joyce and Eliot have remade the tradition in their own image. When Adorno, who is nothing if not dialectical, speaks of "negating" the past, he does not mean that we should forget it, but sublate it in the Hegelian sense. That sublation necessarily involves some selective-or if you preferactive forgetting.

And it is to "active forgetting" that I'd like to return-not as a literary phenomenon but as a way of Being-in-the-world. You began by observing that the person who makes the shopping list is not the same person who later reads it. Presumably in the case of the shopper whatever forgetting occurs is more accidental than active. But your notion that such forgetting is at once "disturbing" and "liberating" gets us to Nietzsche. So please explain. What in your view is desirable about active forgetting, and how do we weigh the "uses" against the "abuses" in an age that suffers from historical amnesia, and where the average attention span is the length of a tweet.

JS: If that's what Adorno's dialectic amounts to, it sounds awfully close to Eliot's theory and closer still to Bloom's "revisionary ratios." I'm not sure I could slide a piece of printer-paper between them. 
As for my pet-category of "active forgetting," I would in fact prefer to think of it as a life-force, a well-spring of creativity, a locus of meaning and a source of intoxication. It allows one to be drunken continually on the stars, on virtue, on the single-malt of metaphor-what you will. It is a necessary paradox in referring to a deliberative forgetting (that's not to say conscious, necessarily). In Thus Spake Zarathustra, Nietzsche refers to the highest of the three spirits as the "child spirit"-a spirit of effortless, innocent forgetting, a self-perpetuating wheel, an everlasting Yea, an orgasmic Yes if one wishes to put the bloom back into Molly. Active forgetting is not the opposite of memory: it is the opposite of Freud's dreary parapraxis-memory as a slip of the tongue or pen, a pathology of everyday life. But surely the end of therapy is a flowering forgetfulness, a way of dismissing one's childhood horrors and other repressions, swatting them away like flies, as the old gods once killed us for sport.

Active forgetting bears no relation to the historical amnesia you rue and decry. That slavish, reflexive and above all insipid form of forgetting augurs no innocence, inseminates no joyful wisdom, creates no new value. Molly's ecstatic Yes, Joyce's blooming prose style, and Eliot's breeding lilacs out of the dead land-those are the achievement of a truly active forgetting.

RB: Adorno's theory of aesthetics-especially his engagement with Kant-is, I think, different from Eliot's and Bloom's, but those differences need not detain us here. Nietzsche penned On the Uses and Disadvantages of History for Life-the Second of the Untimely Meditations-at a time when history reigned supreme in the German academy and Leopold von Ranke was its presiding diety. Ranke's famous formulation-that history should be guided by the principle of wie es eigentlich gewesen ["how it actually happened"] led to an obsession with antiquarianism and archivalism. It was against this dusty and musty historical sensibility-one that prized positivism above everything and refused to see the past in dialectical relation to the present-that Nietzsche raised his voice in protest. But one suspects that if our most antithetical of philosophers were alive today he might well argue the opposite. In an epoch that remembers nothing of the 
past and sees the future as an empty horizon, is active forgetting of any use? Have we become so contemporary, that we have destroyed both Tradition and the Individual Talent? And, just to add a little back-spin to these questions, how does our old friend Plato-who at least metaphorically described all of knowledge as remembering-figure into all of this?

JS: I see your point and think we covered some of this ground in our dialogue on the Benighted States. Emerson-whom Nietzsche admired-said "Americans are blessed with amnesia," but he was thinking in a creative, not a moo-cow, register about how a certain kind of amnesia (forgetting Europe) was essential if America was to keep re-inventing itself. If our contemporaries are too lazy or stupid to remember anything about history, then-as Santayana observed-they will indeed be condemned to repeat the past whilst being utterly clueless that they are doing so.

As for Plato, his mythos of memory was just that: a beguiling story about how we forget everything at birth and must be reminded of the truth, philosophical dialectic being a good electric prod to make us recall our Prenatal Mingling with the Forms. It is in the Myth of Er at the end of Republic that Lethe begins its stream of unconsciousness, allowing the dead to forget their former lives and be reincarnated. But this is the stuff of mythos, not logos.

I want to know how you have sorted out the memory/forgetting dialectic as an existential dynamic. Kierkegaard thought Don Giovanni was the best opera ever written because it presents such a stirring example of creative forgetfulness, a bubbly aria of erōsthanatos where forgetting spills over the Don-and us-and reminds us that memory is the devil that drags us to hell.

RB: $\quad$ Er is the Jesus/Finnegan of Greece: the resurrected dead man, the mortal who communes with the immortals, not to mention the eternal forms. As for memory and forgetting, Plato is-seen from one perspective-the opposite not of Nietzsche but of John Locke: we begin with a tabula plena rather than a tabula rasa. Still, I remain curious about the mythos of anamne sis or knowledge-as-memory. In the Meno, Socrates shows how a lowly slave can, with a little dialectical prompting, intuitively 
grasp something as recondite as geometry. I wonder if anamnē sis is a metaphor for a certain kind of introspection, one that leads to a knowledge so real and true that it feels intuitive-i.e., feels as though it is something we have always known. On this reading, Platonic remembering is not knowledge per se, but the innate capacity that reasoning beings have for achieving such knowledge.

In another vein, you suggest that Mozart's Don Giovanni presents a stirring example of creative forgetfulness. If so, then why does he insist that Leporello meticulously record each and every one of his conquests (mille e tres)? The Don does not engage in the dialectical remembering-and-forgetting that we discussed in Nietzsche, Eliot, Joyce, Adorno and Bloom, an intricately choreographed dance between past and present. Rather, he simply empties his mind-and his gonads—with every new woman, and then has his servant add a notch to his bed-post. The Don is a melancholy figure, a precursor of our contemporary hook-up culture, which is more about men bragging to men than about men loving women. He is a perfect example of the shopper who forgets what is on his list, because the list is utterly forgettable. Donna Anna, Donna Julia and Zerlina might as well be cans of soup or tubes of toothpaste. He has always already forgotten them.

JS: It is not the man that interests me. It's the music. I agree with you about the silly man and his shopping list, memorialized in Leporello's catalogue aria. Kierkegaard was wild not about the figure of Don Giovanni, but about the power and vitality of Mozart's operatic treatment of that figure. To speak of DG as a cautionary tale about the dangers of womanizing is feckless moralizing. I won't have it!

But let's return to Plato. I like what you say about the memorymyth being a metaphor for both introspection and intuition. I don't think Plato-hardly a literalist-would defend the idea that our first souls mingled with the eidoi and then forgot them at birth. Surely that's a good story about what it feels like to hit on a thought or have an intuition-that wildly exciting blend of Aha and Eureka and déjà vu. I think Plato lovingly depicts Socrates in mid-insight, self-arrested for hours on some stoa or other, to 
give us the first model of the Intellectual, the one who wrestles with himself between his ears: a mental Milo. That kind of mental agon spills into the agora, and the rest is the history of Western philosophy.

RB: I have no interest in moralizing over the Don-I wish him well as he fucks his way through another thousand señoritas-but I also have no interest in romanticizing him. His forgetting is a matter not of creativity but indifference, even boredom. As for the music, yes, that is a different matter. Never before or since has there been such a brilliant orchestration of aural remembering and forgetting, a summation of all previous music transformed into something startlingly new and unique. But Mozart is no modern. So far from annulling tradition, he becomes its ultimate expression. It is because Mozart perfected a certain musical idiom that Beethoven and Wagner needed to reinvent it, becoming in the process the first musical moderns.

As for Plato, you state the matter beautifully. Lost in the architecture of his own thought, his is a wandering that is also a home-coming, a peripatetikos in which every logical twist and turn is at once a discovery and a recovery. He is the intellectual's Homer-his Iliad the agon of dialectic, his Odyssey the nostos of anamnēsis.

We seem to agree that Plato uses memory to construct Western metaphysics and Nietzsche uses forgetting to deconstruct it. And we've talked about how the moderns and the philosophers handle memory/forgetting. But what about the Romantics? Wordsworth seems to stand at one end of this opposition, Byron at the other. Are they the Plato and Nietzsche of nineteenth-century English poetry?

JS: In fact, Nietzsche deeply admired Byron and saw himalong with Napoleon and Goethe-as artistic versions of the Übermensch. I think Byron's early Sturm und Drang appealed to Nietzsche no less than Byron's frisky ottava rima, his book of laughter and forgetting called Don Juan. Byron claimed that memory gave him no pleasure, and it's no accident that his ironic masterpiece is a long, highly digressive (forgetful) narra- 
tive poem about Europe's greatest playboy. The brio and élan of Mozart's opera suffuse the comic ingenuity and effervescence of Don Juan. The eponymous hero of our poem is, of course, a thousand times less interesting and exciting than the ingenious narrator (Byron), who is-as the poet said- "quietly facetious about everything." Memory-haunted (and anointed) Wordsworth hated every molecule of the mock-epic but kept his own book of gravitas and memory (The Prelude) under lock and key until he died in 1850 . Yes, Byron and Wordsworth are the Evil Twins of British Romanticism. The river of memory runs through all of Wordsworth's best poems, but Byron drinks his epic from Lethe:

And if I laugh at any mortal thing,

'Tis that I may not weep; and if I weep

'Tis that our nature cannot always bring

Itself to apathy, for we must steep

Our hearts first in the depths of Lethe's spring

Ere what we least wish to behold will sleep.

Thetis baptized her mortal son in Styx;

A mortal mother would on Lethe fix. (Don Juan IV, 4)

The best way to put to sleep our mortal woes is to practice forgetfulness, a fully active, vital and creative forgetting that liberates us from too much memory, too much antiquarianism, too much slavish adherence to rules, regulations and other nightmares that keep us from dreaming up news that stays news. Only a heart well-steeped in Lethe will spring to Life.

RB: You have eloquently pleaded Byron's case for forgetting. But what's the other side of the dialectic-of Wordsworthian memory? The author of "Tintern Abbey" is arguably the first great poet of temporal relativity, the precursor to Proust, Mann, Joyce and Woolf. His "spots of time" anticipate Joyce's epiphany, and his preference for kairos over chronos looks forward to Beckett. Where do you locate Wordsworth in relation to Plato? Are Wordsworth's "clouds of glory" simply another version of Plato's anamnēsis?

JS: The verse paragraph you cite comes from the "Intimations Ode": 
Our birth is but a sleep and a forgetting:

The Soul that rises with us, our life's Star,

Hath had elsewhere its setting,

And cometh from afar:

Not in entire forgetfulness,

And not in utter nakedness,

But trailing clouds of glory do we come

From God, who is our home:

Heaven lies about us in our infancy!

Shades of the prison-house begin to close

Upon the growing Boy,

But He beholds the light, and whence it flows,

He sees it in his joy;

The Youth, who daily farther from the east

Must travel, still his Nature's Priest,

And by the vision splendid

Is on his way attended;

At length the Man perceives it die away,

And fade into the light of common day.

It does sound rather Platonic but it also sounds Heideggerian. We gradually lose the ability to see the "world apparelled in celestial light." That forgetfulness is not really what Nietzsche meant by Vergesslichkeit. It is its pedestrian cousin. It is "common" forgetting. Perhaps a typology of memory-and- forgetting should be wagered. For certainly Kierkegaard was right to see every act of memory as a creative forgetting insofar as memory is selective, a sculptor releasing from the marble of memory a specific form. I think Wordsworth hoped that "the child is the father of the man" and located in that suggestive paradox the only way that "clouds of glory" will trail us into deadening adulthood. There is something at once childish and childlike about that hope. Byronic hope is based on amor fati, a Greek and Nietzschean love of fate that keeps regenerating us precisely by keeping us awash in Lethe. Ultimately, these ambitions are different ways of sculpting chronos into kairos. Byron so feared chronos devouring him that he lived ten lifetimes in his thirty-six years. Wordsworth hobbled to eighty and never stopped tinkering with his one-man epic about the growth of his own mind. 
RB: Perhaps Wordsworth's “celestial light" has more to do with Heidegger's truth-as-unforgetting (alettheia) than with Plato's knowledge-as-recollection (anamnēsis). Here the German distinction between Vergesslichkeit (forgetfulness) and Vergessenheit (oblivion) is perhaps relevant. The former indicates a forgetting that is partial and selective, while the latter refers to a comprehensive failure of memory, one in which the individual doesn't simply forget but loses virtually all awareness or consciousness of a thing.

Heidegger is alive to this distinction in "Anaximander's Saying," where he writes "The oblivion of Being (Seinsvergessenheit) is the oblivion (Vergessenheit) of the difference between Being and beings." What does Heidegger mean in this cryptic formulation? I think he means that when we forget the difference between "Being and beings" we forget our prelinguistic origins, our experience of the world before it was contained within those categories of language that enable us to apprehend objects, actions, relationsin short "beings."

And where does Wordsworth fit into this? He tells us that the soul comes not "in entire forgetfulness" or "utter nakedness," but "trailing clouds of glory." But how is this possible? If we do not and cannot have prelinguistic memories-if language is the necessary precondition for all mental activity-then how can we ever recover the "celestial light" of Being? Wordsworth, Nietzsche and Heidegger all propose the same answer: we remember the difference between Being and beings by remembering that man is an "artistically creating subject." Once we accept the contingency of language, once we acknowledge that our empirical codes are "made" rather than "found," then we can understand the essential connection between aesthetics and aisthanesthai, between our capacity to perceive beauty and the processes of sensuous perception itself. Here is how Nietzsche puts the matter in "On Truth and Lies in a Nonmoral Sense":

Only by forgetting [Vergessen] this primitive world of metaphor can one live with any repose, security, and consistency: only by means of the petrification and coagulation of a mass of images which originally streamed from the primal faculty of human imagination like a fiery liquid, only in the invincible faith that this sun, 
this window, this table is a truth in itself, in short only by forgetting that he is himself an artistically creating subject, does man live with any repose, security and consistency.

Notice that here Nietzsche recommends neither Vergessenbeit nor Vergesslichkeit but Erinnerung (memory). To break out of the routine of settled usage, to live as an artistically creating subject rather than in security and repose is to remember the contingency of language. Nietzsche is, for once, in the same camp as Heidegger and Wordsworth. But I'm left wondering what to do with Plato. Certainly Heidegger is riffing on him when he transforms "recollection" into "unforgetting"?

JS: I scent theoretical fantasy the way Don Giovanni scents women. How could we possibly know anything about a "primitive world of metaphor"? Certainly, that is a conjecture based on what seems to have followed from it. How can we intuit anything about "the primal faculty of human imagination" except by examining what appear to be its traces, its trailing clouds? Maybe these early intuitions are what Nietzsche called "early Greek thinking" (he has a book with that title). Philosophy is clearly something that happens after the fall into secure categories. But how can we presume to know anything about the "artistically creating subject" that lived before the dawn of language?

RB: For Nietzsche and Heidegger the "traces" of primal imagination are present everywhere, recoverable like so many archeological deposits in verbal etymologies. As the linguistic paleontologist applies hammer to word, the sedimentation of usage falls away and the metaphor within stands revealed, a compact fossil of meaning. You say that you scent "theoretical fantasy" the way Don Giovanni scents a woman. Consider your metaphors, which mix the olfactory with the visual. Fantasy derives from phantasia (appearance, mental image, representation) and phantazein (to make visible or present to the eye or mind); theory comes from theorrein (to look at, behold, perceive, consider, contemplate), but is also related to theōros (spectator) and thea (an act of seeingfrom which we get "theatre"). When Heidegger raises the question 
of the difference between Being and beings he is fundamentally asking how we render intelligible what is sensible; how we conceptualize (theōrein) our perceptions (phantasia is Vorstellung) of the world; how we "see" our own way of "seeing."

According to Nietzsche we accomplish this by unpacking the "metaphors, metonymies and anthropomorphisms" that define our world. That is why Heidegger describes language as the "House of Being," and why he believes that the poet (Dichter) is a species of philosopher (Denker). That is also why the poem the world calls "Tintern Abbey," Wordsworth called "Lines." For it is through "lines" of poetry-through language—that we know the world "Of eye, and ear-both what they half create / And what perceive."

Which returns us to the question of Plato and Heidegger. Knowledge-as-recollection (anamnēsis) imagines reality as intelligibility, a situation in which the poet is superfluous. Truth-asunforgetting imagines reality as sensibility, a situation in which the poet is supreme. Under the circumstances, I think we can agree that Wordsworth's "remembering” is more Heideggerian than Platonic, yes?

JS: I think the "Intimations Ode" traces and trails its sensuous hints of immortality taken from the childhood of the imagination, and the "celestial light" that once "appareled" the world is precisely the world in which we do not forget to ask the question of Being. So I would agree that there is something Heideggerian about Wordsworthian remembering-and-forgetting. But I have to say I prefer the poet's lyric evocations to the philosopher's more abstruse musings and jargon. But so did Heidegger. Poetry jars Being into place, the better to see it. Philosophy theorizes from a necessary distance, a canny spectator but not even close to the gazelle, leaping, sipping the liquid horizon.

Regarding that horizon of intuition, let me wonder/wander a little as we perhaps reach to the end. A riverruns through all our intuitions, from that metaphorical jouissance of early Greek thinking (Thales babbled that all is Water!) to the spontaneous overflows of Wordsworth, to the novelistic rejoicing that allows us to spring into streams of consciousness, nourishing the blooms 
of an everlasting Yea. Mnemosyne and Lethe form a confluence in these evocations and intuitions as beautifully mysterious, as piquant and profound, as the shopping list I just fished out, written by someone else called "James" an age ago.

RB: Heidegger wrote abstracted poetry and Wordsworth wrote distracted philosophy. Must we choose between their anecdotal jarrings, between the "dominion" they achieved over the "slovenly wilderness," whether in Todtnauberg or Grasmere?

As for Mnemosyne and Lethe, you launch them breast-bybreast into the River of Recollection, a couple of sleek mermaids in a synchronized swimming competition, each sounding bells on the buoys of culture as they proceed around their watery course. But I prefer to envision our dynamic duo as a couple of superannuated bathing beauties from yesteryear, drowsily sunning themselves on a litter-strewn beach, one nostalgically clutching a photo album in her liver-spotted hands, the other droolingly lost in the age-addled limbo of incipient Alzheimer's. Do they achieve "confluences" of "evocation and intuition," or does each remain enclosed in her solitary world of self-regard?

You conclude (shades of Carlyle and Molly Bloom) with the everlasting Yea. Stranded as I am in the American Heartland I would rather end-as I suspect I shall-with the everlasting Moo. Here is Nietzsche's description of the confrontation between the history-haunted man who remembers and the care-free cow who forgets: "A human being may well ask the animal: 'Why do you not speak to me of your happiness but only stand and gaze at me.' The animal would like to answer, and say: 'The reason is I always forget what I was going to say'-but then he forgot this answer too, and stayed silent."

JS: To amend Wittgenstein, if a moo-cow could speak, we would not be able to understand it. Its form of life-and its form of forgetfulness-are unspeakable. 